\title{
EFFECTS OF AGE ON DIABETES- AND INSULIN-INDUCED CHANGES IN PANCREATIC LEVELS OF $\alpha$-AMYLASE AND ITS mRNA
}

\author{
SUN-KEE KIM ${ }^{a, b, c}$, LOUAN. M. CUZZORT ${ }^{\mathrm{b}}$ and EDWARD D. ALLEN ${ }^{\mathrm{a}}$ \\ ${ }^{a}$ Research Service, V.A. Medical Center, Ann Arbor, MI 48105, Departments of ${ }^{b}$ Anatomy and Cell \\ Biology, Medical School, and 'Biologic and Material Sciences, School of Dentistry, University of \\ Michigan, Ann Arbor, MI (U.S.A.)
}

(Received September 25th, 1990)

\section{SUMMARY}

During aging, protein synthesis undergoes decremental changes in many organs and tissues. In the pancreas, as well as in other exocrine glands, the rate of protein synthesis declines with age. However, it is unknown whether this decline is related to intrinsic aging changes which affect the secretory cell function. In this study, we compared the ability of pancreatic acinar cells to synthesize amylase and its messenger RNA (mRNA) in response to insulin treatment of young and old rats rendered diabetic with streptozotocin (STZ). In STZ-induced diabetic rats, amylase protein and its mRNA levels were reduced drastically in the pancreas of young and old groups. Injections of these diabetic rats with insulin increased pancreatic amylase mRNA contents significantly in both young and old rats. Insulin also increased proportions of amylase protein synthesis in the pancreas of both age groups. These results indicate that the pancreatic cells remain effective during aging in their transcriptional activity for functional amylase mRNA in response to an exogenous stimulus of insulin.

Key words: Aging and amylase mRNA synthesis

\section{INTRODUCTION}

Protein synthesis is one cellular function that undergoes decremental changes in many organs and tissues. The two most prominent changes involved are the decline in rates of biosynthesis [1] and the appearance of structurally altered proteins [2] .

Correspondence to: Dr. S.K. Kim, Research Service, V.A. Medical Center, 2215 Fuller Road, Ann Arbor, MI 48105, U.S.A. 
We have shown previously that rates of synthesis of secretory proteins decline progressively with age in rat pancreas [3] and parotid glands [4 7]. This age-related decline in rates of synthesis of these proteins does not appear to be related to pathologic changes in the glandular structures [8].

It is unclear, however, whether the decline in the steady state rates of protein synthesis in these glands is due to intrinsic aging changes which affect the process at the level of transcription or translation. The decline in secretory protein synthesis in exocrine, digestive glands could reflect the changes in extrinsic regulatory factors, such as the level of digestive activity or hormonal regulatory mechanisms. Furthermore, the synthesis of different secretory proteins is regulated independently in direct relation to the nutritional contents of the diet. In the pancreas, amylase synthesis decreases and peptide proenzyme synthetic increases with a decrease in carbohydrates and a corresponding increase in protein in the diet $[9,10]$. Thus, it is necessary to compare changes involving a specific secretory protein at different ages to determine the effects of aging on secretory protein synthesis.

In the pancreas, insulin affects the level of amylase and its synthesis. In animals rendered diabetic with either alloxan or streptozotocin (STZ), pancreatic amylase levels reduce significantly $[11-16]$. The in vivo administration of insulin to diabetic animals reverses this decline in pancreatic amylase content $[14,15]$. The rate of amylase synthesis increases and this increase is specific for amylase but not for total pancreatic proteins $[14,16]$. These studies indicate a selective effect of insulin on pancreatic amylase gene expression. The large difference in amylase mRNA levels before and after insulin treatment of diabetic rats provides an excellent system for the studies of aging effects on mRNA transcription.

In the present study, we have investigated whether the transcriptional activity of amylase gene becomes impaired during aging. This was done by comparing the changes in levels of amylase and its mRNA during STZ-induced diabetogenesis and in response to subsequent insulin stimulation in young and old rats. The changes in amylase mRNA levels were compared with the levels of mRNA of a non-secretory protein, actin.

\section{MATERIALS AND METHODS}

\section{Animals}

Male Sprague-Dawley rats, obtained from Harlan Sprague-Dawley Inc. (Indianapolis, IN), were used in this study. Young rats were about 2 months of age and weighed $200-250 \mathrm{~g}$, while old rats were about 24 months old and weighed $450-650$ g. These rats were given a single intraperitoneal injection of STZ (Sigma, St. Louis, MO). Each rat received $65 \mathrm{mg} / \mathrm{kg}$ body weight of STZ in $10 \mathrm{mM}$ citrate buffer (pH 4.5 ) and $0.9 \% \mathrm{NaCl}[16]$ to induce diabetes. Uninjected rats of comparable ages served as controls. Diabetic rats were either used on day 6 or treated with insulin starting on day 7. Diabetic rats in both age groups were given daily injections of 2 
units $/ 100 \mathrm{~g}$ body weight of Lente insulin for 3 days. (Eli Lily and Co., Indianapolis, IN). In addition, a group of young diabetic rats was given 4 units $/ 100 \mathrm{~g}$ body weight of insulin for 3 days. Thus, the following groups of both young and old rats were studied: control, diabetic 6 days following the injection of STZ (D6), and diabetic rats receiving insulin injections for 3 days after being diabetic for 6 days (D6I3).

\section{Serum glucose level determination}

The serum level of glucose was measured using an assay kit available commercially (Sigma, St. Louis). Blood was collected from rats by cutting off the tips of their tails.

\section{Amylase assays}

The pancreatic amylase level was determined by its activity according to Bernfeld [18], using startch as the substrate. Pancreatic contents of amylase among different groups were compared based on the DNA content of the gland as previously described $[4,17]$. The DNA content was determined by the diphenylamine method of Burton [19].

\section{RNA extraction}

Total unfractionated RNA was extracted from the pancreas using essentially the same procedures as described by Chirgwin et al. [20]. Only the RNA samples that showed two sharp ribosomal RNA bands after separating by electrophoresis on agarose gel [21] were used for further studies. The ratio of $A_{260} / A_{280}$ of the RNA samples ranged from 1.8 to 2.14 and the DNA contamination was less than $1 \%$.

\section{Northern blots}

RNA samples were denatured with formaldehyde by heating for $15 \mathrm{~min}$ at $55^{\circ} \mathrm{C}$. After electrophoresis on $2.2 \mathrm{M}$ formaldehyde- $1 \%$ agarose gel, the RNA was transferred to nitrocellulose filters [21]. The filter was washed in 3× SSC (standard sodium citrate: $0.15 \mathrm{M}$ sodium chloride and $0.015 \mathrm{M}$ sodium citrate), air dried, and baked for $3-4 \mathrm{~h}$ at $80^{\circ} \mathrm{C}$ under vacuum to fix the RNA to the filter. After hybridization (described below), autoradiographs were prepared using XO-matic AR film (Kodak, Rochester, NY, U.S.A.).

\section{Dot blots}

RNA samples were diluted, denatured as described above, and applied to nitrocellulose filters using a Minifold I (Schleicher and Schuell, Keene, NH) as a guide. The filters were dried and baked as described above. After hybridization, the dots were cut out and radioactivity was counted in a Beckman scintillation counter (LS 9800).

\section{Probe generation and determination of saturating concentration}

Hybridization was carried out with antisense mRNA riboprobes generated using 
a commercially available kit (Promega Biotech, Madison, WI) as described in our previous work [17]. The specific activities of the probes were around 6 and $4 \times 10^{7}$ $\mathrm{cpm} / \mu \mathrm{g}$ RNA for amylase and actin, respectively. The saturating probe concentration was determined by hybridizing nitrocellulose filters containing spots of an equal amouont of RNA to increasing concentrations of riboprobe. Hybridization was carried out using the saturating probe concentration and as described by Maniatis et al. [21] overnight at $55^{\circ} \mathrm{C}$. After hybridization, blots were rinsed 3 times (1, 5 and $10 \mathrm{~min}$ each) with a solution containing $2 \times$ SSC and $0.1 \%$ SDS (sodium dodecyl sulfate) at room temperature. Blots were further washed 2 times in a solution of $0.1 \times$ SSC and $0.1 \%$ SDS at $55^{\circ} \mathrm{C}$ for $30 \mathrm{~min}$.

\section{Isolation of pancreatic acinar cells}

The procedure used to isolate pancreatic acini was essentially that of Williams et al. [22]. Briefly, the procedure employs two buffered solutions, Krebs-Henseleit bicarbonate buffer (KHB), used to isolate acini, and HEPES-buffered Ringer (HR), used to suspend acini for experiments. Isolated acini were obtained by collagenase digestion of the pancreas, and mechanical dissociation by repeated pipetting through polypropylene pipets. Following filtration through $150 \mu \mathrm{m}$ mesh nylon cloth, acini were layered over $4 \%$ BSA in KHB and allowed to settle to the bottom of tubes.

The acini were pooled, allowed to settle through $\mathrm{HR}$, and incubated in polycarbonate Erlenmeyer flasks in a shaker bath for $30 \mathrm{~min}$ at $37^{\circ} \mathrm{C}$ in $4 \mathrm{ml}$ of fresh $\mathrm{HR}$ solution containing $2 \mu \mathrm{Ci} / \mathrm{ml}$ (spec. act.: $500 \mathrm{Ci} / \mathrm{mmol}$ ) of $\left[{ }^{35} \mathrm{~S}\right]$ methionine (Amersham, Arlington Heights, IL). The incubation was stopped by adding excess cold methionine $(20 \mathrm{mM})$. The acini were sonicated after washing in $0.9 \% \mathrm{NaCl}$ and suspending in deionized distilled water. Aliquots of samples were used to determine perchloric acid (PCA)-insoluble radioactivity, to quantitate DNA [19] after extracting it by hot PCA $(0.5 \mathrm{~N})$, and to obtain the water soluble protein fraction (WSP). The WSP was used to determine amylase levels [18] and separate proteins by polyacrylamide $(10 \%)$ gel electrophoresis. After electrophoresis, the amylase band was identified as described previously [7], cut out, solubilized in NCS (Amersham) and used to determine radioactivity by scintillation counting. The total amount of radioactivity incorporated into amylase was calculated and used to estimate the percentage of the total radioactivity in PCA-insoluble proteins that was incorporated into amylase.

\section{RESULTS}

\section{Body weights and serum glucose levels}

Non-fasting levels of serum glucose increased to values about 5 times that of the control level 6 days after the injection of STZ in rats of both age groups (Table I). Only those rats with the serum glucose level of higher than 400 were considered to be diabetic and used for study. Three daily injections of the diabetic rats with insulin 
TABLE I

SERUM GLUCOSE LEVELS AND PANCREATIC CONTENTS OF AMYLASE

\begin{tabular}{|c|c|c|c|c|}
\hline \multirow[t]{2}{*}{ Treatment } & \multicolumn{2}{|l|}{ Young rats } & \multicolumn{2}{|l|}{ Old rats } \\
\hline & $\begin{array}{l}\text { Serum glucose } \\
(\mathrm{mg} / 100 \mathrm{ml})\end{array}$ & $\begin{array}{l}\text { Amylase } \\
\text { (units/ug DNA) }\end{array}$ & $\begin{array}{l}\text { Serum glucose } \\
(\mathrm{mg} / 100 \mathrm{ml})\end{array}$ & $\begin{array}{l}\text { Amylase } \\
\text { (units/ug DNA) }\end{array}$ \\
\hline $\begin{array}{l}\text { Control } \\
\text { D6 }\end{array}$ & $\begin{array}{l}117.0 \pm 9.2(7) \\
564.0 \pm 18.4^{*}(5)\end{array}$ & $\begin{array}{l}4.04 \pm 0.34(10) \\
136 \pm 0.26^{*}(5)\end{array}$ & $\begin{array}{r}99.3 \pm 8.8(4) \\
\left.59.8^{*}\right)\end{array}$ & $\begin{array}{l}3.82 \pm 0.21(4) \\
17\end{array}$ \\
\hline $\begin{array}{l}\text { D6I3 } \\
(2 \mathrm{U})\end{array}$ & $436.1 \pm 43.5^{*}(6)$ & $1.54 \pm 0.22^{*}(5)$ & $151.3 \pm 58.7(5)$ & $1.50 \pm 0.17^{*}(3)$ \\
\hline $\begin{array}{l}\text { D613 } \\
(4 \mathrm{U})\end{array}$ & $150.0 \pm 14.9(6)$ & $1.82 \pm 0.18^{*}(6)$ & & \\
\hline
\end{tabular}

D6, diabetic rats, 6 days after the injection of STZ.

D613, diabetic rats injected with insulin for 3 days.

Data represent mean \pm S.E.M.

Numbers in parentheses denote the number of rats in each group.

*Indicates the values that are significantly different $(P \leq 0.05)$ by unpaired Student $t$-test from their corresponding control values.

( 2 units $/ 100 \mathrm{~g}$ body wt) reversed and lowered the serum glucose level significantly (Table I). The wide variations in the glucose level in insulin injected rats were related to the fact that the blood test was performed about $24 \mathrm{~h}$ after the injection of insulin. The blood sugar level fluctuated much more widely in young rats and required 2 times the dose of insulin ( 4 units $/ 100 \mathrm{~g}$ ) to lower the blood sugar to near control level in 3 days.

The young, STZ injected rats gained only about $10 \mathrm{~g}$ in 6 days while the uninjected control rats gained about $50 \mathrm{~g}$ during the same time period. The injections of insulin for 3 days increased the body weight of the young diabetic rats by about $50 \mathrm{~g}$. On the other hand, the older rats lost about $70 \mathrm{~g}$ in 6 days following STZ injection. The insulin injections of these old diabetic rats increased their body weight about $50 \mathrm{~g}$ in 3 days.

\section{Amylase protein and $m R N A$ levels}

The pancreatic amylase contents were reduced significantly in STZ-induced diabetic rats of both age groups as compared to those in respective control groups (Table I). Following injections of the diabetic rats with insulin for 3 days, the glandular amylase contents were not significantly higher than in diabetic rats of both age groups.

The amylase mRNA levels were also reduced significantly to about $12 \%$ and $20 \%$ of the control levels in young and old diabetic rats, respectively (Table II). After 3 daily injections of insulin ( 2 units $/ 100 \mathrm{~g}$ body wt), the pancreatic contents of amylase mRNA increased significantly to almost $60 \%$ of the control level in the older rats 
TABLE II

PANCREATIC LEVELS OF AMYLASE AND ACTIN mRNA

\begin{tabular}{lclll}
\hline & $\begin{array}{l}\text { Amylase } \\
\text { c.p.m.Ing RNA }\end{array}$ & $\begin{array}{l}\text { \% of } \\
\text { control }\end{array}$ & $\begin{array}{l}\text { Actin } \\
\text { c.p.m./ng RNA }\end{array}$ & $\begin{array}{l}\text { \%of } \\
\text { control }\end{array}$ \\
\hline Young rats & & & & \\
$\quad$ Control (4) & $280.00 \pm 33.32^{*}$ & & $3.02 \pm 0.38$ & \\
D6 (4) & $32.55 \pm 7.04$ & 11.6 & $3.16 \pm 0.22$ & 104.6 \\
D613 (2 U) (4) & $116.53 \pm 20.77^{*}$ & 41.2 & $3.89 \pm 0.86$ & 129.8 \\
D613 (4 U) (5) & $88.62 \pm 8.47^{*}$ & 31.3 & $5.28 \pm 1.27$ & 175.7 \\
& & & & \\
Old rats & $363.37 \pm 15.39^{*}$ & & $2.11 \pm 0.30$ & \\
Control (3) & $71.38 \pm 28.46$ & 19.7 & $1.83 \pm 0.42$ & 86.7 \\
D6 (4) & $215.73 \pm 56.10^{*}$ & 59.4 & $1.76 \pm 0.44$ & 83.4 \\
D613 (3) & & & \\
\hline
\end{tabular}

The mRNA levels were determined by dot-blot analyses using ${ }^{32}$ P-labelled antisense riboprobes generated from amylase or actin cDNAs as described in the Materials and Methods section.

D6, diabetic rats, 6 days after the injection of STZ.

D6I3, diabetic rats injected with insulin for 3 days.

Numbers in parentheses denote the number of rats in each group.

Data represent mean \pm S.E.M. The value for each rat represents the average of at least 4 blots.

*Indicates the values that are significantly different $(P \leq 0.05)$ by unpaired Student $t$-test from their corresponding D6 values.

(Table II). Insulin injections of the same dose to younger diabetic rats increased only to about $40 \%$ of the control level (Table II). Even after injections of twice the dosage of insulin ( 4 units/100 $\mathrm{g}$ body $\mathrm{wt}$ ) to young diabetic rats, pancreatic amylase mRNA levels did not increase much more. Despite the varying amounts of amylase mRNA present in the pancreas of control, diabetic and insulin-injected rats of both ages, the size of this mRNA appeared to be about the same (Fig. 1).

Neither STZ nor insulin injections had any major effect on actin mRNA levels in the pancreas of young or old rats (Table II, Fig. 1). Unlike amylase mRNA levels, actin mRNA levels did not change significantly in the pancreas of control, diabetic and diabetic rats treated with insulin in either age group.

Incorporation of $\left[{ }^{35} S\right]$ methionine into total protein and amylase in isolated pancreatic acinar cells

Upon incubation of isolated pancreatic acinar cells in the presence of [35S ] methionine, the percentage of the label in amylase, which accounted for about $11 \%$ of the total radioactivity in proteins in the control groups, were reduced to about 2 and 4\%, respectively, for young and old diabetic rats (Table III). Insulin injections increased this percentage of the label incorporation into amylase in both age groups, however, this increase was again much greater in the older rats $(8 \%)$ than 

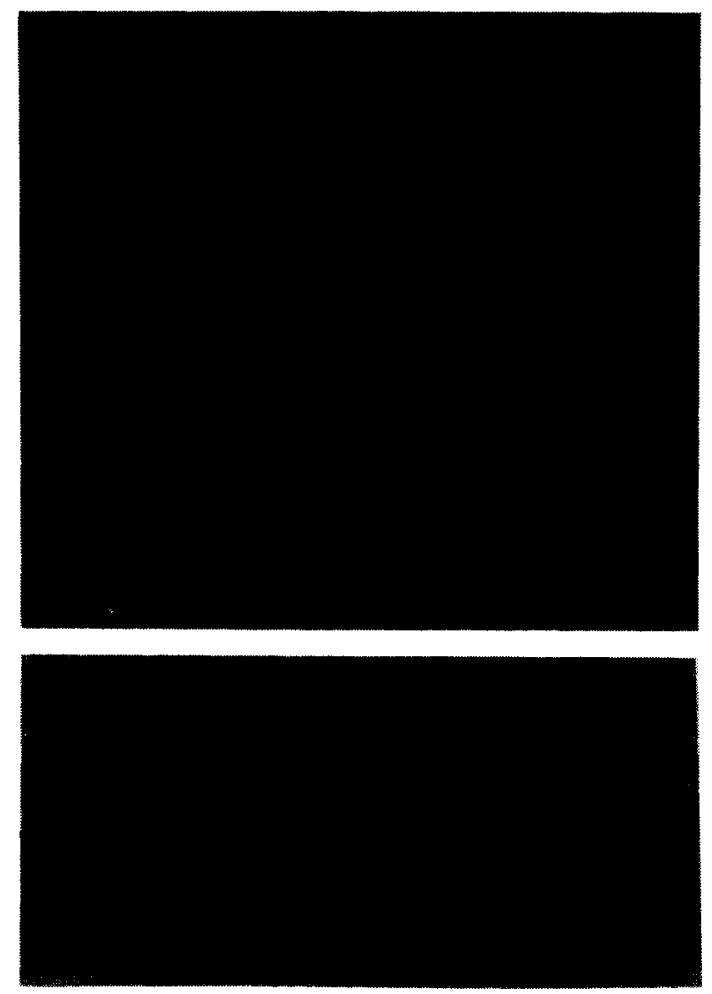

Fig. 1. Northern blot showing the differences in pancreatic amylase and actin mRNA levels in control, diabetic and insulin-injected rats. Two identical blots were made with pancreatic RNA, obtained from young (lanes $4-7$ ) and old (lanes $1-3$ ) rats. One blot was hybridized with ${ }^{32}$ P-labelled antisense amylases riboprobe, shown in $\mathrm{A}$. The other blot was hybridized with actin riboprobe labelled as above. shown in B. In both age groups, amylase mRNA levels are reduced significantly in diabetic rats (lanes 2 and 5 for old and young rats, respectively) as compared to their corresponding controls in lanes 1 (old) and 4 (young). Following 3 daily injections of insulin (lane 3) the mRNA increases in amount to about $60 \%$ of the control level in old rats. In young rats, insulin injections of the same dosage as above (lane 6) or even twice the dosage (lane 7) do not increase the mRNA levels as much as in the older rats. Despite varying amounts of amylase mRNA, the molecular size of the mRNA appears to be the same in all groups. In comparison to amylase mRNA, actin mRNA levels (B) do not vary significantly among different rats in both age groups.

in their younger counterparts $(<5 \%)$. The amount of radioactivity incorporated into total pancreatic proteins decreased also in diabetic rats and increased after injecting these rats with insulin (Table III). However, the radioactivity amounts were not corrected for possible differences in the amino acid precursor pool sizes before and after STZ injection, or in different age groups. 
TABLE III

INCORPORATION OF $\left[{ }^{35}\right.$ S]METHIONINE INTO ACID-INSOLUBLE PROTEINS AND AMYLASE

\begin{tabular}{|c|c|c|}
\hline & 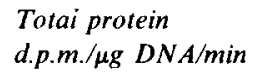 & $\begin{array}{l}\% \text { of radioactivity } \\
\text { in amylase }\end{array}$ \\
\hline \multicolumn{3}{|l|}{ Young rats } \\
\hline Control & $94.33 \pm 5.57(7)$ & $11.81 \pm 0.75(7)$ \\
\hline D6 & $64.07 \pm 7.63(7)$ & $2.02 \pm 0.54^{*}(4)$ \\
\hline D6I3 (2 U) & $63.17 \pm 7.28(5)$ & $4.84 \pm 0.49^{*}(6)$ \\
\hline D6I3 (4 U) & $70.80 \pm 10.10(3)$ & $4.06 \pm 0.31^{*}(3)$ \\
\hline \multicolumn{3}{|l|}{ Old rats } \\
\hline Control & $58.27 \pm 13.28(5)$ & $10.86 \pm 2.45$ \\
\hline D6 & $43.57 \pm 10.06(5)$ & $3.77 \pm 1.21^{*}(4)$ \\
\hline D6I3 & $68.13 \pm 25.23(4)$ & $8.27 \pm 1.05(3)$ \\
\hline
\end{tabular}

D6, diabetic rats, 6 days after the injection of STZ.

D613, diabetic rats injected with insulin for 3 days.

Data represent mean \pm standard deviation.

Numbers in parentheses indicate the number of rats in each group.

*Indicates the values that are significantly different $(P \leq 0.05)$ by unpaired Student $t$-test from their corresponding control values.

\section{DISCUSSION}

The changes in the pancreatic level of amylase and its mRNA induced by STZdiabetes and subsequent insulin treatment in this study are fairly consistent with the changes described previously in studies of experimental diabetes involving young animals $[11-16]$. The pancreatic contents of amylase and its mRNA, which are significantly reduced in young and old diabetic rats, increase after insulin injections of these diabetic rats. Amylase levels in the pancreas of insulin-treated rats were not higher than those of the diabetic rats in both age groups. This low level of pancreatic amylase in insulin-injected rats is likely to be due to the increased secretory activity which, in turn, is related to the elevated digestive activity. The digestive activity is probably stimulated by insulin as evidenced by weight gains after insulin injection in both age groups.

These effects of STZ and insulin on pancreatic amylase and its mRNA are those which are expected in young rats in view of the previous findings mentioned above. However, the effect of insulin on amylase mRNA levels in the older rats is unexpected. Surprisingly, the extent of increase in amylase mRNA following insulin injections was significantly greater in the pancreas of the older rats (to about $60 \%$ of the control level) than in the younger ones (only to $40 \%$ of the control level). Even twice the dosage of insulin did not have a greater effect in increasing the glandular content of amylase mRNA in young rats. Since amylase mRNA levels in the pan- 
creas of young rats increase to the control level in about 7 days [16, our unpublished observation], it appears that the effect of insulin is not as immediate in these rats as in the older ones. There are many other possible explanations for the lower level of pancreatic amylase mRNA in the younger rats than in their older counterparts, and it is not the intention to compare the response to insulin by the pancreas of young and old rats.

The significant point within the scope of this study is the fact that the pancreatic acinar cells of the older rats remain capable of synthesizing amylase mRNA when stimulated by an exogenous supply of insulin. The exact mechanism by which insulin regulates amylase synthesis is unknown. A recent study of an amylase/chloramphenicol acetyltransferase (CAT) hybrid in transgenic mice has shown that insulin regulates amylase synthesis at the level of transcription, rather than by regulating the processing of mRNA or its stability [23]. Thus, it appears that the transcriptional efficiency of the pancreatic acinar cells in the rat is maintained duirng aging, at least for the amylase gene.

The insulin-mediated increase in amylase mRNA levels is accompanied by a parallel increase in the percentage of radioactive methionine incorporation into pancreatic amylase in young and old rats. Thus, it appears that the pancreatic acinar cells retain the efficiency in amylase gene transcription, as well as in its mRNA translation, during aging. These are unexpected results based on many previous studies which have indicated that the ability of cells to synthesize proteins in many organs [1,2], including the pancreas [3], and to adapt to changes in external physiological stress [25] decline during aging. When the diet of young rats is changed to a complex carbohydrate diet, the levels of pancreatic amylase increase in young rats, while the diet change has no significant effect on the levels of the same enzyme in old rats, suggesting that adaptation to extrinsic stimuli reduces with age [25].

It has been suggested that insulin and glucose mediate such adaptive changes in amylase levels in relation to diet changes [26]. In fact, insulin secretion [27], as well as synthesis [28,29], has been shown to decrease with age in rats and this decrease might be responsible for the reduced adaptive response in amylase synthesis in old rats. However, the results from the present study, based on the expression of the amylase gene in the pancreas, indicate that the adaptive response to insulin is not reduced when it is provided externally.

The effects of diabetes and insulin on amylase and its mRNA in the pancreas appear to be specific for this secretory protein. Neither diabetes nor insulin had any significant effect on pancreatic levels of actin mRNA, an mRNA for a non-secretory protein in both age groups, as shown in this study. Also, previous studies have shown that, even among pancreatic enzymes of diabetic rats, only the amylase activity was markedly decreased while activities of trypsinogen and chymotrypsinogen were increased $[11,15]$. Insulin appears to have an inverse effect on amylase and chymotrypsinogen mRNA levels [16]. Similarly, insulin seems to affect amylase selectively in rat parotid glands as well $[17,24]$. Thus, it remains to be determined 
how transcriptional and translational activities for other secretory proteins in the pancreas are affected by changing levels of insulin during aging.

\section{ACKNOWLEDGEMENTS}

This investigation was supported in part by the Veterans Administration and by USPHS Research Grants DE-08109 from the National Institute of Dental Research and AG-07159 from the National Institute on Aging, National Institutes of Health, Bethesda, MD 20892.

\section{REFERENCES}

1 A. Richardson, The relationship between aging and protein synthesis. In J.R. Florini (ed.), C.R.C. Handbook of Biochemistry in Aging. Boca Raton, Florida, 1981, pp. 79-101.

2 M.E. Reff, RNA and protein metabolism. In Finch and Schneider (eds.), Handbook of the Biology of Aging, van Nostrand Reinhold, New York, 1985.

3 S.K. Kim, P.A. Weinhold, D.W. Calkins and V.W. Hartog, Comparative studies of the age-related changes in protein synthesis in the rat pancreas and parotid gland. Exp. Gerontol., 16 (1981) $91-100$.

4 S.K. Kim, P.A. Weinhold, S.S. Han and D.J. Wagner, Age-related decline in protein synthesis in the rat parotid gland. Exp. Gerontol., 15 (1980) $71-85$.

5 S.K. Kim, Age-related changes in the cellular level of amylase and protein synthesis in the rat parotid gland. J. Dent. Res., 60 (1981) 738-749.

6 S.K. Kim, D.W. Calkins, P.A. Weinhold and S.S. Han, The changes in the synthesis of exportable and nonexportable proteins in parotid glands during aging. Mech. Ageing Dev., 18 (1982) 239-250.

7 S.K. Kim and P.P. Arisumi, The synthesis of amylase in parotid glands of young and old rats. Mech Ageing Dev., 31 (1985) 257-266.

8 S.K. Kim, Changes in the secretory acinar cells of the rat parotid gland during aging. Anat. Rec., 209 (1984) 345-354.

9 J. Schick, H. Kern and G. Scheele, Hormonal stimulation in the exocrine pancreas results in coordinate and anticoordinate regulation of protein synthesis. J. Cell Biol., 99 (1987) 1569-1574.

10 J. Schick, R. Verspohl, H. Kern and G. Scheele, Two distinctive adaptive responses in the synthesis of exocrine pancreas results in coordinate and anticoordinate regulation of protein synthesis. $\mathrm{Am}$. J. Physiol., 10 (1984) G611-G616.

11 A. Ben Abdeljili, J.C. Palla and P. Desnuelle, Effect of insulin on pancreatic amylase and chymotrypsinogen. Biochem. Biophys. Res. Commun., 18 (1965) 71.

12 J.T. Snook, Effect of diet, adrenalectomy, diabetes, and actinomycin D on exocrine pancreas. Am. J. Physiol., 215 (1968) 1329-1333.

13 I. Christophe, J. Camus, M. Deschodt-Lanckman, J. Rathe, P. Robberreccht, M.C. VandermeersPieret and A. Vandermeers, Factors regulating biosynthesis, intracellular transport and secretion of regulating biosynthesis, intracellular transport and secretion of amylase and lipase in the rat pancreas. Horm. Metab. Res., 3 (1971) 393-403.

14 H.D. Söling and K.O. Unger, The role of insulin in the regulation of $\alpha$-amylase synthesis in the rat pancreas. Eur. J. Clin. Invest., 2 (1972) 199-212.

15 M. Korc, Y. Iwamoto, H. Sankaran, J.A. Williams and I.D. Goldfine, Insulin action in pancreatic acini from streptozotocin-treated rats I. Stimulation of protein synthesis. Am. J. Physiol., 3 (1981) G56-G62.

16 M. Korc, D. Oberbach, C. Qunito and W.J. Rutter, Pancreatic islet-acinar cell interaction: Amylase messenger RNA levels are determined by insulin. Science, 213 (1981) 351-353.

17 S.K. Kim, L.M. Cuzzort, R.M. McKean and E.D. Allen, Effects of diabetes and insulin on alphaamylase messenger RNA levels in rat parotid glands. J. Dent. Res.. 69 (1990) 1500-1504. 
18 P. Benfeld, Amylases, alpha and beta. Methods Enzymol., 1 (1955) 149_158.

19 K. Burton, A study of the conditions and mechanism of diphenylamine reaction for the colorimetric estimation of deoxyribonucleic acid. Biochem. J., 162 (1956) 315-323.

20 J.M. Chirgwin, A.E. Pryzybyla, R.J. MacDonald and W.J. Rutter, Isolation of biologically active ribonucleic acid from sources enriched in ribonuclease. Biochemistry, 18 (1979) 5294-5299.

21 T. Maniatis, E.F. Fritsch and J. Sambrook, Molecular Cloning, a Laboratory Manual, Cold Spring Harbour Lab., 1982.

22 J.A. Williams, M. Korc and R.L. Dormer, Action of secretogogues on a new preparation of functionally intact, isolated pancreatic acini. Am. J. Physiol., 235 (1978) E517-524.

23 L. Osborn, M.P. Rosenberg, S.A. Keller, C.N. Ting and M.H. Meisler, Insulin response of a hybrid amylase/CAT gene in transgenic mice. J. Biol. Chem., 263(32) (1988) 16519-16522.

13 L.C. Anderson, Effects of alloxan diabetes and insulin in vivo on rat parotid gland. Am. J. Physiol., 245 (1983) G431-G437.

25 R.E. Greenberg and P.R. Holt, Influence of aging upon pancreatic digestive enzymes. Digest. Dis. Sci., 31 (1986) $970-977$.

26 G. Adler and H.F. Kern, Regulation of exocrine secretory process by insulin in vivo. Horm. Metab. Res., 7 (1975) 290-296. (Abstract)

27 E. Reaven, G. Gold and G.M. Reaven, Effects of age on glucose stimulated insulin release by the beta-cell of the rat. J. Clin. Invest., 64 (1979) 591--599.

28 G. Gold, G.M. Reaven and E.P. Reaven, Effect of age on proinsulin and insulin secretory patterns in isolated rat islets. Diabetes, 30 (1981) $77-82$.

29 S.Y. Wang, P.A. Halban and J.W. Rowe, Effects of aging on insulin synthesis and secretion: differential effects on preproinsulin messenger RNA levels, proinsulin biosynthesis, and secretion of newly made and preformed insulin in the rat. $J$. Clin. Invest., 81 (1988) 176-184. 